REVIEW OF HISTORICAL SCIENCES 2018, VOL. XVII, NO. 3

http://dx.doi.org/10.18778/1644-857X.17.03.10

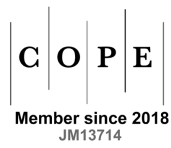

MiChAËL GREEN

UnIVERSITY OF COPENHAGEN*

\title{
Huguenot impact on the education of the Dutch nobility ${ }^{1}$
}

\begin{abstract}
his article aims to present the outcomes of research conducted by the author on the Huguenots as educators for the Dutch nobility. This topic has been chosen because during the entire period covering the second half of the $16^{\text {th }}$ century until the mid-18 ${ }^{\text {th }}$ century, many French Calvinists, also known as Huguenots, were either escaping from religious persecution by Catholic authorities, or emigrating for economic reasons to the United Provinces of the Netherlands. The first wave of emigrants reached its peak in 1572 , after the St Bartholomew Day's massacre. The second wave of migrants peaked in 1686-1687. Research conducted after the 300
\end{abstract}

*Danish National Research Foundation Centre for Privacy Studies, DNRF138, e-mail:mgr@teol.ku.dk.

${ }^{1}$ The present article is a free translation and slightly updated version of my Russian language article: Gugienoty $i$ ich wkład $w$ wospitanije niderlandskogo dworianstwa, 'Problemy socjalnoj istorii i kultury sriednich wiekow i ranniego nowogo wremienii' 2015, vol. XII, pp. 269-292. It is based on my previous publications on Huguenot education and aims to synthesise their conclusions in relation to the Dutch nobility: M. Green, Bridging the English Channel: Huguenots in the Educational Milieu of the English Upper Class, 'Paedagogica Historica' 2018, vol. LIV, No. 4, pp. 389-409; idem, The Orange-Nassau family at the educational crossroads of the Stadholder's position (1628-1711), 'Dutch Crossing: Journal of Low Countries Studies', http://www.tandfonline.com/doi/full/10.1080/030965 64.2016.1186925; idem, The Huguenot Jean Rou (1638-1711): Scholar, Educator, Civil Servant, Paris 2015; idem, Huguenot Educators for European Nobility 16301715, 'The Huguenot Society Journal' 2013, vol. XXX, No. 1, pp. 73-92; idem, Educating Johan Willem Friso of Nassau-Dietz (1687-1711): Huguenot Tutorship at the Court of the Frisian Stadtholders, 'Virtus - Yearbook of The History of the Nobility' 2012, vol. XIX, pp. 103-124; idem, The importance of Religion in the Educational Theory of Jean Rou, 'Proceedings of the Huguenot Society of Great Britain and Ireland' 2010, vol. XXIX, No. 3, pp. 408-417. 
year-anniversary of the Revocation of the Edict of Nantes (1685), which demanded that Huguenots convert to Catholicism under pain of death, showed that between fifty- and one-hundred-and-twenty thousand Huguenots left France and settled in Protestant countries across Europe following the Revocation of the edict of Nantes ${ }^{2}$. The United Provinces became the main place of refuge for fleeing Huguenots, from which some of them continued their journey into the Holy Roman Empire, Ireland, England, and even beyond the sea to North America.

It is important to note that Huguenot emigration was not a single event, but a long process which created Huguenot communities outside of France ${ }^{3}$. Usually such communities were established around a church, or 'Temple' as the Huguenots used to call their prayer house. In the United Provinces, migrants of the first wave were called 'Walloons', as also among them were residing in the Southern Netherlands's region called Wallonia, and their churches were subsequently called 'Walloon churches' (fr. Eglise Wallone). In England, it was Edward VI who allowed construction of Strangers Reformed Churches in 1550. There were several churches of this kind in London, and each one had its own parishioners ${ }^{4}$.

Who formed the majority of the Huguenots-émigrés? Although the majority were to some extent literate because of the Calvinist doctrine which stressed the importance of reading the Bible, only a small percentage were educated: craftsmen, doctors, lawyers, religious ministers - these were the graduates of the Huguenot academies, such as Puylaurens, Saumur, Sedan, Montauban, and Namur, where several generations of Huguenot scholars were

${ }^{2}$ M. Yardeni, Le refuge protestant, Paris 1985; D. van der Linden, Experiencing Exile: Huguenot Refugees in the Dutch Republic, 1680-1700, Farnham 2015; M. Magdelaine, R. von Thadden, Le Refuge Huguenot, Paris 1985; R. Gwynn, The Huguenots in Britain, the 'Protestant International' and the Defeat of Louis XIV, [in:] From Strangers to Citizens: The Integration of Immigrant Communities in Britain, Ireland, and Colonial America, 1550-1750, ed. R. Vigne, London 2001, pp. 412-424.

${ }^{3}$ For more information on Huguenots in different countries, see M. Yardeni, Le refuge Huguenot: Assimilation et culture, Paris 2002. For detailed analysis of Huguenots in England: R. Gwynn, Huguenot Heritage: The History and Contribution of the Huguenots in Britain, $2^{\text {nd }}$ revised ed., London-New York 2001; idem, The Huguenots of London, Brighton-Portland 1998. For Huguenot education in England, see M. Green, Bridging the English..., pp. 389-409.

${ }^{4}$ H. Dunthorne, Britain and the Dutch Revolt 1560-1700, Cambridge 2013, p. 136. See also A. Pettegree, Foreign Protestant communities in sixteenth-century London, Oxford 1986; G.B. Beeman, Notes on the sites and history of the French Churches in London, London 1905. 
educated $^{5}$. Within two decades following the Edict of Nantes (1598), which granted Huguenots some religious liberty, many such academies had been opened ${ }^{6}$. The graduates of these institutions were of particular interest for parents seeking tutors of various skills for their children.

The study of Huguenot educational impact on European culture is important, since Huguenots were employed in different Protestant countries across Europe. Yet until now the topic of Huguenot education has been surprisingly absent from the agenda of prominent researchers of the Huguenot diaspora. Evidence for this is the recently published A Companion to the Huguenots, edited by Raymond A. Mentzer and Bertrand Van Ruymbeke, which despite aiming to present 'an encompassing portrait of the Huguenots' does not dedicate any space to Huguenot educational practices and ideas among its twenty chapters ${ }^{7}$. Nevertheless, in the past ten years three collective volumes were published with the goal of introducing the academic world to the problems faced by French-speaking tutors and schools in the $16^{\text {th }}-19^{\text {th }}$ centuries. However, the United Provinces are absent from these volumes altogether. The first of these volumes, edited by Geraldine Sheridan and Vivien Rosen-Prest, Les éducateurs Huguenots dans l'éspace europeén à l'époche moderne, is an attempt to demonstrate who the Huguenot educators and their pupils were. At the same time, some of the articles are dedicated to school education ${ }^{8}$. Geographically, the studies mostly include the Holy Roman Empire, Ireland and partially England. The second volume, Le précepteur francophone en Europe, XVIIe-XIXe siècles, is edited by Vladislav Rjéoutski and Alexander Tchoudinov (published both in Russian and French) ${ }^{9}$. Despite the

${ }^{5}$ W. Frijhoff, Uncertain Brotherhood, [in:] Memory and Identity: The Huguenots in France and the Atlantic Diaspora, eds B. Van Ruymbeke, R.J. Sparks, Columbia 2003, pp. 128-170, here p. 142.

${ }^{6}$ In this context, academy is a term that refers to a Reformed higher education establishment, the equivalent of a university. K. Maag, The Huguenot Academies: Preparing for an Uncertain Future, [in:] Society and Culture of the Huguenot World 1559-1685, eds R.A. Mentzer, A. Spicer, Cambridge 2002, pp. 139-156; M. Yardeni, Le refuge Huguenot..., pp. 66-71.

${ }^{7}$ A Companion to the Huguenots, eds R.A. Mentzer, B. Van Ruymbeke, Leiden 2016. The quote is taken from the description provided by the publisher.

${ }^{8}$ Les Huguenots éducateurs dans l'espace européen à l'époque moderne, eds G. Sheridan, V. Prest, Paris 2011.

${ }^{9}$ Le précepteur francophone en Europe, XVIIe-XIXe siècles, eds V. Rjéoutski, A. Tchoudinov, Paris 2013. 
broad title, most articles are dedicated to the history of French tutors in Russia and a smaller part once again dedicated to England and the German principalities. Therefore, despite the significant impact of these books on bringing the Huguenot tutors to light, they completely leave out the United Provinces of the Netherlands, where a significant number of such tutors was present ${ }^{10}$. Moreover, the individual studies present only a fragmented picture based mostly on case-studies, making it impossible to reach broader conclusions. Therefore, I would like to fill this gap and introduce the reader to the Huguenot tutors in the Netherlands, their noble employers, and the private relationship they established.

From early in the fourth decade of the $17^{\text {th }}$ century until the first decades of the $18^{\text {th }}$ century, many Huguenots were employed in educating the Princes of Orange and Counts of Nassau, the Stadtholders of various Dutch provinces. Let us first examine what the position of the Stadtholder meant. In his monumental work on Dutch history, Jonathan Israel states that the position had been in existence from the time of the Spanish rule in each of the provinces, and was similar to the role of a royal representative. Stadtholders were given military command as their main purpose was to defend the territories. After the Dutch Revolt at the end of the $16^{\text {th }}$ century, which was partly led by William I of Orange, Stadtholder of Holland, all of the Stadtholders' positions across the United Provinces were occupied by members of the Orange-Nassau dynasty; in Holland, the Orange branch was based in the largest province with its administrative centre in The Hague, and the more junior Nassau branch were based in Friesland, with their administrative centre in Leeuwarden. Not solely focusing on military tasks, the Stadtholder was responsible for defending the Reformed faith. Due to his military rank, the Stadtholder of Friesland was under command of the Stadtholder of Holland ${ }^{11}$. The

${ }^{10}$ One other volume in Russian published in 2018, Ideal of Noble Education in Europe: Seventeenth through Nineteenth Centuries [Idieat wospitanija dworianstwa $w$ Jewropie: XVII-XIX wieka], eds V. Rjéoutski, I. Fediukin, W. Berelowitch, Moscow 2018, also largely focuses on Russia, with some references to France, but not to the United Provinces.

${ }^{11}$ J. Israel, The Dutch Republic: Its Rise, Greatness, and Fall 1477-1806, Oxford 1995, pp. 300-306, 486-487, 489-490, 537-539. See also the revised paperback version published in 2002, and H.H. Rowen, The Princes of Orange: The Stadholders in the Dutch Republic, Cambridge 1988. The Dutch word stadhouder is written in English either as 'stadtholder' or 'stadholder'. 
childless William III (1650-1702), Prince of Orange, named Johan Willem Friso of Nassau-Dietz (1687-1711) to succeed to his title, thus uniting the two branches of the family. According to J.L. Price, the Stadtholder was particularly important as a unifying factor in Dutch society ${ }^{12}$. As we will see below, both branches, despite their different status, shared similar standards for the education of their children ${ }^{13}$.

In the $17^{\text {th }}$ century, the French court was considered the model for noblemen around Europe. Therefore, the aristocracy considered it imperative that their children knew French courtly manners and had fluent command of the language ${ }^{14}$. The latter gained particular importance when Frederik Hendrik of Orange (1584-1647) established the princely court at The Hague in the first quarter of the $17^{\text {th }}$ century $^{15}$. The Stadtholder was no longer just a military commander; he was the centre of the court, the first noble of the land, and who needed to be surrounded by courtiers who knew how to behave accordingly ${ }^{16}$. Willem Frijhoff notes that previously in 1608 an anonymous poem had been published, which mentioned that every Dutch daughter was dreaming of a gallant 'monsieur', its author complaining of the necessity to know manners and language that were foreign to him ${ }^{17}$. Frijhoff also states that French manners, together with the Republic of Letters (an unofficial scholarly society at the time), were the main catalysts for the popularisation of the French language in high society ${ }^{18}$. Here we should not forget the

${ }^{12}$ J.L. Price, The Dutch Republic in the Seventeenth Century, HoundmillsLondon 1998, p. 21. See also W. Frijhoff, M. Spies, 1650: Hard-Won Unity, Assen 2004.

${ }^{13} \mathrm{~S}$. Groenveld, Gemengde gevoelens. De relaties tussen Nassaus en Oranjes als stadhouders en kapiteins-generaal, [in:] Nassau uit de schaduw van Oranje, eds S. Groenveld, J.J. Huizinga, Y.B. Kuiper, Franeker 2003, pp. 23-45.

${ }^{14}$ R.G. Asch, Nobilities in Transition 1550-1700: Courtiers and Rebels in Britain and Europe, London 2003; M. Motley, Becoming a French Aristocrat: The Education of the Court Nobility 1580-1715, Princeton 1990.

${ }^{15}$ For general information on the Orange-Nassau dynasty, see the classic work of N. Japikse, De Geschiedenis van het Huis van Oranje-Nassau, vol. I-II, Hague 1938.

${ }^{16}$ K.J. Riemens, Esquisse historique de l'enseignement du Français en Hollande du XVIe au XIXe siècle, Leiden 1919, p. 80.

${ }^{17}$ W. Frijhoff, Verfransing? Franse taal en Nederlandse cultuur tot in de revolutietujd, 'Bijdragen en mededelingen betreffende de geschiedenis der Nederlanden' 1989, vol. CIV, pp. 592-609, here p. 595.

${ }^{18} \mathrm{Idem}$, Des origines à 1780: l'émergence d'une image, 'Histoire de la diffusion et de l'enseignement du français dans le monde' 1998, pp. 8-20; idem, 
role of French in trade and science. The importance of French grew even more during the mid-reign of Louis XIV (1643-1715) when the French court became the most important centre of high-society in Europe, attracting not only noblemen but also artists, writers, and scholars. One should keep in mind, as Norbert Elias has shown, that the French king kept his status both through distribution of financial benefits and regulating access to himself among others through etiquette ${ }^{19}$. Even so, despite the republican character of the United Provinces, the princely courts both in The Hague and Leeuwarden were important cultural and political centres ${ }^{20}$.

\section{Huguenot ideas on education}

Having become acquainted with the context of high society in the $17^{\text {th }}$ century, we will now turn our attention to the use that Dutch nobility made of Huguenots in the field of education. Perhaps the most important question concerns the educational programme proposed by the Huguenots for children of the elite. Unfortunately, a lack of sources means that answering this question poses a serious problem. Nonetheless, there is at least one source that tells in detail how such an educational programme for a noble child would have looked.

This source is Projet pour l'éducation d'un jeune seigneur by Jean Rou (1638-1711), a Huguenot scholar, written in around 1690-91 for the use of the future head tutor, or gouverneur, of Johan Willem Friso, Count of Nassau ${ }^{21}$. Rou came from a Parisian bourgeois family. His parents were Jacques Rou, a procureur at the Parliament of Paris, and Isabelle Toutin, who came from a family of artists. After the murder of his father and the death of his mother, at the age of fourteen Rou became an orphan under the care of his uncle who sent him to the Academy of Saumur. In 1659, he became magister of philosophy and half a year later passed his

L'usage du français en Hollande, XVIIe-XIXe siècles: propositions pour un modèle d'interprétations, 'Etudes de linguistique appliquée' 1990, nº 78, pp. 17-26.

${ }^{19}$ N. Elias, The Court Society, $2^{\text {nd }}$ ed., Oxford 2006.

${ }^{20}$ O. Mörke, Sovereignty and Authority. The Role of the Court in the Netherlands in the First Half of the Seventeenth Century, [in:] Princes, Patronage, and the Nobility. The Court at the Beginning of the Modern Age c. 1450-1650, eds R.A. Asch, A.M. Birke, Oxford-New York-Toronto 1991, pp. 455-477, here p. 463.

${ }^{21}$ It was impossible to determine the identity of the tutor Rou had in mind. On the identification of the pupil, see M. Green, The Huguenot..., chapter 4. 
law exams, as was customary in France at the time. He worked as a lawyer at the Parliament of Paris for several years but soon enough quit his stable job and solid income in favour of the writing pen. In the following years, he authored several translations of Spanish authors and one extremely popular original work entitled: Tables de l'histoire universelle ancienne (1672) which was dedicated to the French Dauphin and recognised by no less than Louis XIV himself ${ }^{22}$. Commissioned by the King himself, the sequel to this book extended the scope of covered historical periods to his own day, brought Rou's career in France to an abrupt end; the book was banned and the author thrown into the Bastille, following accusations of anti-Catholic sentiments and the misuse of royal privilege. After his release, with the help of his patron, the Duke de Montausier, Rou began to tutor, at first in France and then in England and the United Provinces where in 1689 he was appointed translator of the Estates General. He died in The Hague in $1711^{23}$. The memoirs that he wrote at the end of his life provide not only information on himself, but also contain many unpublished or lost works - either his own, or those of his friends, as well as some of his own correspondence. These memoirs shed light both on aspects of daily life and the intellectual climate at the time. The memoirs were edited by Francis Waddington and published in France in 1857, by the Société pour l'histoire du Protestantisme Français ${ }^{24}$.

The text of the Projet contains the following idea on education, as expressed by Rou: 'The goal is to get the child to know his Creator and get him accustomed to prayer, to fear Him and serve Him. It is the first and the main principle of good upbringing, after which there will be advancement in all the other subjects ${ }^{25}$. This thesis can be considered one of the most important principles of Rou's educational vision. It corresponds with one of the principles of Christian humanism as propagated by Erasmus of Rotterdam ${ }^{26}$. In his text, Rou more or less follows Erasmian principles. Mornings and evenings the child must pray so that he has a constant reminder of

22 J. Rou, Tables de l'histoire universelle ancienne, Paris 1672; idem, Tables de l'histoire universelle moderne, Paris 1675.

${ }^{23}$ See M. Green, The Huguenot..., chapter 1.

${ }^{24}$ J. Rou: Mémoires inédits et opuscules, ed. F. Waddington, vol. I-II, Paris 1857.

${ }^{25}$ Ibidem, vol. I, p. 196. All translations are my own.

${ }^{26}$ Desiderius Erasmus, De pueris statim ac liberaliter instituendis, libellus et novus et elegans, Paris 1536. See also W.H. Woodward, Desiderius Erasmus Concerning the Aim and Method of Education, Cambridge 1904. 
the Divine presence in his life. In the mornings, the child should read chapters of the Bible. These should be explained by his tutor. Fear of God, explicitly mentioned by Rou, was particularly important for the Calvinists, as is evident in Confessio Belgica (widely used in the United Provinces) and in the diaries of Willem Frederick of Nassau (1613-1664), the grandfather of Johan Willem Friso ${ }^{27}$. After lunch the child can proceed with 'secular' subjects, among them history, literature, geography, and heraldry. For Rou, just as for Erasmus, it was important to use the study material for moral instruction and to find the connections between various study subjects. In this way, history can help in studying heraldry, the Bible in morals and virtue, even geography and literature in the development of personality, and so on.

At the same time, although Rou based his own thought on humanistic principles, there was certainly a contemporary aspect to his educational vision. He assumed that the child needs to 'get to know the world', in contradiction to Erasmian ideas but closely related to those of the English philosopher John Locke, who spent several years in the United Provinces ${ }^{28}$. As did Locke, Rou endorsed focusing attention on subjects that would be helpful for the young nobleman in his future tasks, instead of learning only for the sake of learning. Latin and Greek should be learned on the basis of personal need, and one should never to overuse them in a conversation. Here Rou in fact differs from Locke, who considered Greek to be irrelevant for a nobleman and Latin as useful only for those who wanted to dedicate themselves to science. Curiously, the immensely popular and highly criticised book of Baltassare Castiglione, Il libro del cortegiano, read that the courtier should not only have a good command of Latin, but also Greek, since much has been written in both of these languages about different subjects $^{29}$. Rou also stressed, somewhat echoing Erasmus, that lessons should be made interesting, making study more of a game than hard labour ${ }^{30}$.

${ }^{27}$ Willem Frederik: Gloria parendi. Dagboeken van Willem Frederik, Stadhouder van Friesland, Groningen en Drenthe, 1643-1649, 1651-1654, eds J. Visser, G.N. van der Plaat, Hague 1995, pp. 43, 112.

${ }^{28}$ J.W. Yolton, John Locke and Education, New York 1971; P. Gay, John Locke on Education, New York 1971; S.J. Savonius-Wroth, The Educational Revolution of John Locke and his Huguenot allies, [in:] Les Huguenots éducateurs..., pp. 155-186.

${ }^{29}$ B. Castiglione, Il libro del cortegiano, Venice 1528.

${ }^{30}$ Desiderius Erasmus, op. cit. 


\section{Personal relationship with the tutor}

The most striking difference between Rou's educational vision and those of other prominent educators of the early modern period is in his attitude towards the relationship between tutor and pupil. Here we enter the sphere of privacy, since according to Rou, a relationship between pupil and tutor would need to be very close. The tutor should treat his pupil as a brother. Erasmus, on the contrary, viewed the relationship as that of father and son. The relationship between brothers is assumed to be a very close one, and therefore Rou's proposal of brotherly treatment towards the pupil can be seen as an attempt to construct a private zone of trust with the latter. Considering private human relations, one can define such privacy zones, by starting with the self and then move into various private circles - the nuclear family, the household, and so on. Therefore, the tutor-pupil relationship that Rou aims to establish contains a great measure of trust. Thus, he creates an idea of what can be defined as a new private zone, standing right behind the one of the child and his immediate family ${ }^{31}$.

\section{Education of Dutch noblemen}

Having examined an educational treatise written by a Huguenot, we can draw our attention to several examples that show the extent to which Rou's ideas corresponded with the demands of parents and with the ideas of other educators. First of all, it is necessary to point out that the most prominent and well-known Huguenot educator in the United Provinces was the theologian Andre Rivet (1572-1651). He was employed as head tutor to William II (1626-1650), son of Frederik Hendrik (1584-1647), Prince of Orange and Stadtholder of Holland, and Amalia van Solms (1602-1675). As mentioned above, this couple established a princely court in The Hague and promoted the use of French language. Along the same lines, they invited Rivet, who was working at the time at the University of Leiden

${ }^{31}$ For more on privacy and private zones, see M. Birkedal Bruun, Privacy in Early Modern Christianity and Beyond: Traces and Approaches, 'Annali Instituto storico italo-germanico / Jahrbuch des italienisch-deutschen historischen Instituts in Trient' 2018, vol. XLIV, No. 2 [forthcoming]. On tutor-pupil relationship and privacy, see also: M. Green, L.C. Nøgaard, French Influence on Dutch Egodocuments: Privacy and the Orange-Nassau and Bentinck correspondences, 1632-1705 [submitted]. 
as chair of Theology, to become head tutor to their son ${ }^{32}$. Samuel Chappuizeau (1625-1701), a renowned Huguenot scholar, held the position of tutor to the future Stadtholder William III of Orange (1650-1702). Other known examples of Huguenot tutors include three generations of the Nassau's: Jean de Morel, head tutor to Hendrik Casimir II (1657-1696); Jean Lemonon, head tutor to Johan Willem Friso (1687-1711) ${ }^{33}$, and the minister Isaac Lamigue, who acted as a personal preacher to Johan Willem Friso and taught French to his son, William IV (1711-1751).

The main sources on a head tutor's responsibilities are the directives given by parents when appointing a new person to this position. In 1632, Frederik Hendrik wrote in his appointment of Rivet that it was the head tutor's responsibility to teach William II the fear of God, good manners and modesty, which were imperative to him by birth. ' $[\mathrm{H}] \mathrm{e}$ will design a method of exercises $[\ldots]$ that William will follow, and maintain discipline that will be necessary to achieve this result, as well as guide him and go with him everywhere, where needed ${ }^{34}$. As is clearly seen from the text, Frederik Hendrik's ideas correspond with the principles of Christian humanism that were also reflected in Rou's work. While still a small child, William II wrote his motto, most likely under the scrupulous eye of his head tutor Rivet: 'Nothing without God' (fr. Rien sans Dieu) which shows that the Christian message of his teaching was well received by the pupil ${ }^{35}$.

Furthermore, the emphasis that Frederik Hendrik put on the duty of the head tutor to guide and follow his pupil brings us back to the zones of privacy. In fact, Frederik Hendrik decided that Rivet would become part of the close circle surrounding the prince, a person of trust and confidence. Therefore, the placement of the head tutor into what we called the zone of privacy immediately following that of the child-immediate family is supported by the father's words.

${ }^{32}$ H.H. Rowen, op. cit., p. 60. For biographical information and Rivet's role in the court at The Hague, see A.G. Opstal, Andre Rivet: Een invloedrijk hugenoot aan het hof van Frederik Hendrik, Hardewijk 1937. Rivet dedicated a book on education to his pupil, published after the end of his appointment: Instruction du prince chrestien, Leiden 1642. See also L. Kooijmans, Liefde in opdracht: Het hofleven van Willem Frederik van Nassau, Amsterdam 2000.

${ }^{33}$ Lemonon, Johannes, [in:] Frieslands Hoogeschool en het Rijks Athenaeum te Franeker, ed. W.B.S. Boeles, vol. II, Leeuwarden 1879, pp. 329-330.

${ }^{34}$ Commission from Frederik Hendrik to André Rivet, February 12, 1632, Royal House Archives [hereinafter: RHA], MS. A15-V-1.

${ }^{35}$ Rien sans Dieu, 1637, RHA, A15-XII-3-9. 
Similar ideas can be traced in the appointment of Frederik van Nassau van Zuylestein (1624-1672), illegitimate uncle and head tutor to William III, which was made by William's mother Mary Stuart, widow of William II, and his grandmother, Amalia van Solms ${ }^{36}$. Here the head tutor was to educate the young prince in the Reformed tradition of virtues and good manners, as well as to teach him Latin and other study subjects, and once again to accompany him in everything he does or everywhere he goes. Here we also see that the head tutor is located within the third private circle after the self and the family. Two Huguenots were employed with William III: Samuel Chappuizeau taught him French and Abraham Raguineau, a painter, taught him reading, writing, mathematics and drawing.

Religious education, as we have seen above, played an important role, as the Stadtholder was to defend the Reformed faith ${ }^{37}$. Of course, this emphasis on religion was not unique to the Dutch Reformed Church. A young Englishman, Philip Perceval, undertook a Grand Tour in France, where according to a letter sent by his Huguenot tutor, Alexandre de Rasigade, the young man attended a Synod in Saumur and listened to religious debates of Reformed theologians such as Etienne de Bray ${ }^{38}$.

Curiously enough, the large amount of time dedicated to religious education was not well-received by the parents, who demanded to reduce it. A vivid example is described by Jean Rou in his memoirs, when in 1680, during his tutorship of the sons of Cornelis van Aerssen van Sommelsdijk (a close supporter of William III) and the Huguenot noblewoman Marguerite du Puys de Saint André Montbrun, he entered into a conflict with the mother. Despite demonstrating to Rou her vivid interest in religion, by inviting him to join her in attending various preachings, she claimed that he devoted too much time to religion at the expense of other disciplines. Pierre Jurieu, a famous Huguenot theologian and a close friend of Jean Rou, tried to resolve the conflict but was unsuccessful. Rou was dismissed and turned to an administrative career for the time being.

While the Dutch families who hired Huguenot tutors hoped that these Frenchmen would teach their children courtly manners, only

${ }^{36}$ Commision pour le Sr. De Suylesteyn comme gouverneur de son Altesse, September 27, 1659, RHA, MS. B12-27.

${ }^{37}$ J. Israel, op. cit., p. 305.

${ }^{38}$ Letter from Alexandre de Rasigade to Robert Southwell, Saumur, November 3/13, 1677, British Library, Add MS 46954 B, f. 201-202. 
a few had a true idea of how the French Court functioned. André Rivet was among those who had actually served in a noble household in France, as a pastor to the Duke de Le Trémouille and his wife up until 1620, when he was invited to teach at Leiden University. He therefore had hands-on experience with courtly manners ${ }^{39}$. Jean Rou also had access to the court until the ban on his Tables de l'histoire moderne (1675). The conclusion that can be drawn here is that Dutch families would often be satisfied with a tutor who was French and knew the culture, if a person with proper courtly experience was unavailable to them. It is worthwhile to note that not everyone in the United Provinces was particularly happy with the spread of French culture, however. Jean de Morel was criticised by Johan Maurits, uncle of Hendrik Casimir II, for being 'too French' and therefore not a good example for a Dutch nobleman ${ }^{40}$.

Indeed, besides French language, religion and courtly manners, young aristocrats who were educated by Huguenots studied the usual studia humanitatis; William II read Caesar's De bello Gallico, a Latin history book, thus following the Erasmian principle of combining different subjects ${ }^{41}$, while Rou was reading fables with his pupils to teach them both morals and literature ${ }^{42}$. In such, all prominent humanistic elements were present in their education.

\section{Conclusions}

It can be clearly seen that Huguenots were influenced by Christian humanism as much in their educational ideas as in the practical side of education. The popularity of Huguenots as tutors can be explained by the Huguenot presence in large numbers in Protestant countries, together with the vast importance to high society of the French language, culture and courtly manners. As is evident from the example from the highest Dutch nobility, having at least one Huguenot tutor at the household was almost a given option.

${ }^{39}$ Rivet, [in:] Eug. Haag, Em. Haag, La France protestante ou vies des Protestants Français qui se sont fait un nom dans l'histoire depuis les premiers temps de la Reformation jusqu'à la reconnaissance de principe de la liberté des cultes par l'Assemblée Nationale, vol. I-X, Paris 1846-1859, here vol. VIII, p. 444.

${ }^{40}$ Letter from Johan Maurits to Albertine Agnes, September 15, 1673, behind: J.W. van Sypesteyn, Geschiedkundige bijdragen, bijlagen, IX, Hague 1865.

${ }^{41}$ Willem II to Frederik Hendrik, no place, no day, August 1639, Ick ben bedroeft..., RHA, MS A-14-XI-A-16.

${ }^{42}$ J. Rou: Mémoires..., vol. I, p. 198. 
The fact that Huguenots functioned as tutors to noble families over a long period of time (from late $16^{\text {th }}$ and until early $18^{\text {th }}$ centuries) shows that they acted as intercultural intermediaries between their own culture and that of the countries in which they were employed. As I have shown in my works dedicated to Huguenot education in other countries, they had a unique combination of skills and qualities that were not available in any other group within the population ${ }^{43}$.

\section{Bibliography}

\section{Archival sources}

Royal House Archives, The Hague [RHA]

Commision pour le Sr. De Suylesteyn comme gouverneur de son Altesse, September 27, 1659, MS. B12-27.

Commission from Frederik Hendrik to André Rivet, February 12, 1632, MS A15-V-1.

Rien sans Dieu, 1637, MS. A15-XII-3-9.

Willem II to Frederik Hendrik, no place, no day, August 1639, Ick ben bedroeft..., MS A-14-XI-A-16.

British Library, London

Letter from Alexandre de Rasigade to Robert Southwell, Saumur, November 3/13, 1677, Add MS 46954 B, f. 201-202.

\section{Printed SOURCes}

Castiglione B., Il libro del cortegiano, Venice 1528.

Erasmus Desiderius, De pueris statim ac liberaliter instituendis, libellus et novus et elegans, Paris 1536.

J. Rou: Mémoires inédits et opuscules, ed. F. Waddington, vol. I-II, Paris 1857.

Rivet A., Instruction du prince chrestien, Leiden 1642.

Rou J., Tables de l'histoire universelle ancienne, Paris 1672.

Rou J., Tables de l'histoire universelle moderne, Paris 1675.

Willem Frederik: Gloria parendi. Dagboeken van Willem Frederik, Stadhouder van Friesland, Groningen en Drenthe, 1643-1649, 1651-1654, eds J. Visser, G.N. van der Plaat, Hague 1995.

\footnotetext{
${ }^{43}$ A book on Huguenot education is in preparation by the author of this article.
} 


\section{STUdies}

A Companion to the Huguenots, eds R.A. Mentzer, B. Van Ruymbeke, Leiden 2016. Asch R.G., Nobilities in Transition 1550-1700: Courtiers and Rebels in Britain and Europe, London 2003.

Beeman G.B., Notes on the sites and history of the French Churches in London, London 1905.

Birkedal Bruun M., Privacy in Early Modern Christianity and Beyond: Traces and Approaches, 'Annali Instituto storico italo-germanico / Jahrbuch des italienisch-deutschen historischen Instituts in Trient' 2018, vol. XLIV, No. 2 [forthcoming].

Dunthorne H., Britain and the Dutch Revolt 1560-1700, Cambridge 2013.

Elias N., The Court Society, $2^{\text {nd }}$ ed., Oxford 2006.

Frieslands Hoogeschool en het Rijks Athenaeum te Franeker, ed. W.B.S. Boeles, vol. I-II, Leeuwarden 1879.

Frijhoff W., Des origines à 1780: l'émergence d'une image, 'Histoire de la diffusion et de l'enseignement du français dans le monde' 1998, pp. 8-20.

Frijhoff W., L'usage du français en Hollande, XVIIe-XIXe siècles: propositions pour un modèle d'interprétations, 'Etudes de linguistique appliquée' 1990, $\mathrm{n}^{\circ} 78$, pp. 17-26.

Frijhoff W., Uncertain Brotherhood, [in:] Memory and Identity: The Huguenots in France and the Atlantic Diaspora, eds B. Van Ruymbeke, R.J. Sparks, Columbia 2003, pp. 128-170.

Frijhoff W., Verfransing? Franse taal en Nederlandse cultuur tot in de revolutietujd, 'Bijdragen en mededelingen betreffende de geschiedenis der Nederlanden' 1989, vol. CIV, pp. 592-609.

Frijhoff W., Spies M., 1650: Hard-Won Unity, Assen 2004.

Gay P., John Locke on Education, New York 1971.

Green M., Bridging the English Channel: Huguenots in the Educational Milieu of the English Upper Class, 'Paedagogica Historica' 2018, vol. LIV, No. 4, pp. 389-409.

Green M., Educating Johan Willem Friso of Nassau-Dietz (1687-1711): Huguenot Tutorship at the Court of the Frisian Stadtholders, 'Virtus - Yearbook of The History of the Nobility' 2012, vol. XIX, pp. 103-124.

Green M., Gugienoty $i$ ich wkład $w$ wospitanije niderlandskogo dworianstwa, 'Problemy socjalnoj istorii i kultury sriednich wiekow i ranniego nowogo wremienii' 2015, t. XII, pp. 269-292.

Green M., Huguenot Educators for European Nobility 1630-1715, 'The Huguenot Society Journal' 2013, vol. XXX, No. 1, pp. 73-92.

Green M., The Huguenot Jean Rou (1638-1711): Scholar, Educator, Civil Servant, Paris 2015.

Green M., The importance of Religion in the Educational Theory of Jean Rou, 'Proceedings of the Huguenot Society of Great Britain and Ireland' 2010, vol. XXIX, No. 3, pp. 408-417.

Green M., Nøgaard L.C., French Influence on Dutch Egodocuments: Privacy and the Orange-Nassau and Bentinck correspondences, 1632-1705 [submitted]. 
Groenveld D., Gemengde gevoelens. De relaties tussen Nassaus en Oranjes als stadhouders en kapiteins-generaal, [in:] Nassau uit de schaduw van Oranje, eds S. Groenveld, J.J. Huizinga, Y.B. Kuiper, Franeker 2003, pp. 23-45.

Gwynn R., Huguenot Heritage: The History and Contribution of the Huguenots in Britain, $2^{\text {nd }}$ revised ed., London-New York 2001.

Gwynn R., The Huguenots in Britain, the 'Protestant International' and the Defeat of Louis XIV, [in:] From Strangers to Citizens: The Integration of Immigrant Communities in Britain, Ireland, and Colonial America, 1550-1750, ed. R. Vigne, London 2001, pp. 412-424.

Gwynn R., The Huguenots of London, Brighton-Portland 1998.

Haag Eug., Haag Em., La France protestante ou vies des Protestants Français qui se sont fait un nom dans l'histoire depuis les premiers temps de la Reformation jusqu'à la reconnaissance de principe de la liberté des cultes par l'Assemblée Nationale, vol. I-X, Paris 1846-1859.

Ideal of Noble Education in Europe: Seventeenth through Nineteenth Centuries [Idieat wospitanija dworianstwa w Jewropie: XVII-XIX wieka], eds V. Rjéoutski, I. Fediukin, W. Berelowitch, Moscow 2018.

Israel J., The Dutch Republic: Its Rise, Greatness, and Fall 1477-1806, Oxford 2002.

Japikse N., De Geschiedenis van het Huis van Oranje-Nassau, vol. I-II, Hague 1938.

Kooijmans L., Liefde in opdracht: Het hofleven van Willem Frederik van Nassau, Amsterdam 2000.

Le précepteur francophone en Europe, XVII $-X I X^{e}$ siècles, eds V. Rjéoutski, A. Tchoudinov, Paris 2013.

Les Huguenots éducateurs dans l'espace européen à l'époque moderne, eds G. Sheridan, V. Prest, Paris 2011.

Maag K., The Huguenot Academies: Preparing for an Uncertain Future, [in:] Society and Culture of the Huguenot World 1559-1685, eds R.A. Mentzer, A. Spicer, Cambridge 2002, pp. 139-156.

Magdelaine M., Von Thadden R., Le Refuge Huguenot, Paris 1985.

Mörke O., Sovereignty and Authority. The Role of the Court in the Netherlands in the First Half of the Seventeenth Century, [in:] Princes, Patronage, and the Nobility: The Court at the Beginning of the Modern Age c. 1450-1650, eds R.A. Asch, A.M. Birke, Oxford-New York-Toronto 1991, pp. 455-477.

Motley M., Becoming a French Aristocrat: The Education of the Court Nobility 1580 1715, Princeton 2016.

Opstal A.G., Andre Rivet: Een invloedrijk hugenoot aan het hof van Frederik Hendrik, Hardewijk 1937.

Pettegree A., Foreign Protestant communities in sixteenth-century London, Oxford 1986.

Price J.L., The Dutch Republic in the Seventeenth Century, Houndmills-London 1998. 
Riemens K.J., Esquisse historique de l'enseignement du Français en Hollande du $X V I^{e}$ au XIX siècle, Leiden 1919.

Rowen H.H., The Princes of Orange: The Stadholders in the Dutch Republic, Cambridge 1988.

Van der Linden D., Experiencing Exile: Huguenot Refugees in the Dutch Republic, 1680-1700, Farnham 2015.

Van Sypesteyn J.W., Geschiedkundige bijdragen, bijlagen, IX, Hague 1865.

Woodward W.H., Desiderius Erasmus Concerning the Aim and Method of Education, Cambridge 1904.

Yardeni M., Le refuge Huguenot: Assimilation et culture, Paris 2002.

Yardeni M., Le refuge protestant, Paris 1985.

Yolton J.W., John Locke and Education, New York 1971.

\section{INTERNET SOURCES}

Green M., The Orange-Nassau family at the educational crossroads of the Stadholder's position (1628-1711), 'Dutch Crossing: Journal of Low Countries Studies' 2016, http://www.tandfonline.com/doi/full/10.1080/03096564.201 6.1186925 . 